\title{
ASSESSING THE SEVERITY AND THE INCIDENCE OF CASSAVA ROOT NECROSIS DISEASE (CRND) IN WESTERN DEMOCRATIC REPUBLIC OF CONGO
}

\author{
Bakelana Zeyimo $^{1,6}$, Justin Pita ${ }^{6}$, Mwangu Kuhima ${ }^{3}$, Tevo Ndomateso ${ }^{1,6}$, Mayanza Kingolo ${ }^{1,6}$, Betezi \\ Makuka $^{1}$, Tuwizana Nsimba ${ }^{1}$, Mukendi Tshizembe ${ }^{2}$, Tshiamala Ngeleka ${ }^{2}$, Mahungu Nzola Meso ${ }^{4}$, Monde \\ Godefroid $^{5,6}$, Lema ki Munseki ${ }^{7}$, Tshilenge Kanana ${ }^{7}$ and Kalonji Mbuyi ${ }^{7}$ \\ ${ }^{1}$ National Institute for Agricultural Research Studies (INERA), Mvuazi Research Center, DRC \\ ${ }^{2}$ National Institute for Agricultural Research Studies (INERA),Ngandajika Research Center, DRC \\ ${ }^{3}$ National Institute for Agricultural Research Studies (INERA), Kiyaka Research Station, DRC \\ ${ }^{4}$ International Institute of Tropical Agriculture (IITA) \\ ${ }^{5}$ Institute Faculty of Agricultural Sciences / Yangambi, DRC \\ ${ }^{6}$ West African Virus Epidemiology / WAVE, Abidjan, Ivory-Coast. \\ ${ }^{7}$ Agriculture Faculty - Kinshasa University / DRC \\ http://doi.org/10.35410/IJAEB.2019.4477
}

\begin{abstract}
Cassava is the staple food in the Democratic Republic of Congo (DRC) where both the roots and leaves are consumed. This crop is susceptible to several viral diseases, including Cassava Mosaic Disease(CMD) and Cassava Brown Streak Disease(CBSD) in eastern DRC. Following earlier studies that show root necrosis occurring in western DR Care not due to CBSD but to Cassava Root Necrosis Disease (CRND), an exploratory survey was conducted in western DRC from 2016 to 2017 in order to determine the distribution, the severity and the incidence of this disease (previously known as CBSD-like disease). NGS ( Next Generation Sequencing) results confirmed all the previous negative results obtained using PCR and CBSV primers. This suggests that microorganisms such as bacteria or fungi could be responsible for cassava root necrosis in western DRC and is not CBSD as predicted. Five provinces (Bas-Congo, Kinshasa, Bandundu, Equateur and Kasai-Oriental) were surveyed and data were collected according to the harmonized protocols adopted by countries within the West African Virus Epidemiology (WAVE) project. Statistical tests (ANOVA) performed on our data showed that CRND severity did not vary significantly among the provinces of Kinshasa, Bandundu and Bas-Congo which are the areas most affected by the disease. Bas-Congo and Kinshasa provinces presented the highest maximum disease severity (score 3 and 5 respectively), while Equateur province had the lowest disease severity score. Equateur province also had the highest percentage of healthy plants and few plants presented mild symptoms. The overall average of cassava root necrosis severity in western DRC ranged around $1.88 \pm 0.08$, an approximate score of 2 . The overall mean incidence of CRND in western DRC was $22.24 \pm 2.4 \%$ but reached $100 \%$ in localities considered as hotspots (Lukuakua in Bas-Congo and Nguma in Plateau des Batékés). The behaviour of cassava varieties against CRND is similar with CBSD in East Africa, most of improved varieties and landraces are susceptible to both diseases. Correlation analyses showed a positive correlation $(\mathrm{r}=$ 0.6940) between severity and incidence of CRND. Therefore, Bas-Congo province is the most affected province, while the province of Equateur is the least affected province in western DRC. Further investigations, including genomic surveillance, should also be conducted in the eastern DRC where CBSD is confirmed to know if CRND is found in conjunction with CBSD and to
\end{abstract}


report possible instances of mixed infections. For medium-term disease control, our study suggests that the development and deployment of control measures including cultivars with resistance to CRND and CBSD should be a priority.

Keywords: Severity, Incidence, CRND, CBSD-like, Survey.

\section{INTRODUCTION}

Cassava (Manihot esculenta) production is important to the economy of Democratic Republic of Congo (DRC). It is one of the country's principal crops, with per capita consumption of $353 \mathrm{~kg}$ per year, which is the highest in the world (Mbago et al., 2017). Cassava, a perennial crop originally from South America, was introduced from Brazil into the Congo basin of Africa in 1558 by the Portuguese[1].

In more recent times, farmers in the Congo region, who were used to growing staple crops of millet, banana and yam, willingly adopted cassava as it was pest-free and a reliable crop during drought conditions. At that time, cassava was grown entirely for domestic consumption without any export potential [2].

DRC is the largest consumer of cassava worldwide, with an average consumption of $353 \mathrm{~kg}$ per year per capita, or $145 \mathrm{~kg}$ per capita in cassava flour form. The flour form is worked into a dough known as $f u f u[3]$. The country is also the leading consumer of cassava leaves as a vegetable, as these leaves are rich in proteins, calcium, Vitamin A and Vitamin C. Cassava products manufactured and used in DRC include bakery products using unfermented flour, pulp and wafers, and industrial products such as starch, alcohol and biofuel[4]. Fermented and dried cassava pulp, known as cossettes, is produced through a simple process for human consumption, and is not labor-intensive, while chickwangue is a familiar processed cassava product in DRC [5].There has been a considerable increase in cassava cultivation over the years; approximately $22 \%$ of the cultivated land area in 1959 was planted with cassava[6].

Some fifteen years ago, this cultivation area had increased to over $50 \%$ of the DRC's land area[7].According to an FAO estimate from 2000, 16.5 million tons of cassava was produced from an area of 2 million ha. The southern region accounted for 2.4 million tons from an area of $358,000 \mathrm{ha}[8]$.Nowadays, the production of this important crop in DRC is constrained by several factors, such as pest infestations, inadequate tools for planting, and inadequate infrastructure[8].

Cassava production in Africa is constrained mostly by pests and diseases [9]. Cassava mosaic disease (CMD), caused by cassava mosaic geminiviruses (CMG), is undoubtedly the most important constraint to the production of cassava in Africa in the 21st century [10].The most visible symptom of the disease is the expression of the characteristic leaf mosaic, and young plants (less than 3 months after planting) are more severely affected than old ones. Symptoms range from barely perceptible mosaic to stunting of the plant and extreme reduction of the leaf blades [11]. Epidemics of CMD are devastating, with yield losses varying between 20-90\% ([11], [12], [13]) depending on the virus strain. In the 2000s, DRC experienced a severe outbreak of the CMD caused by the Ugandan variant (EACMV-UG). This virus was detected in most of the country's cassava-growing areas and resulted in significant crop losses ([14],[15]). 
Cassava brown streak disease (CBSD) is another viral disease that constrains cassava production in most parts of East Africa. Root yield loss attributable to CBSD can exceed 70\% [16].. CBSD has long been considered endemic in the coastal zones ([17]; [18]) and affected cassava areas located at low and mid altitudes (below 1000 meters) [19].However, from 2004, outbreaks were reported at altitudes greater than 1000 meters in the Great Lakes region of East Africa and Central Africa [20]. CBSD has been prevalent for several years in various East African and southern African countries including Kenya, Malawi, Mozambique, Tanzania and Uganda [20]. More recently, however, this disease has been reported in eastern DRC and its taxonomic identity has been confirmed through molecular tests [21].

CBSD leaf symptoms include blotchy yellow chlorosis or feathery necrosis, often associated with minor veins, which can appear within the first few months of planting infected cuttings and persist in mature leaves. Brown, round or elongated streak-like lesions can occur on the young green portion of infected stems, but the main economic loss is caused by dry, brown necrotic lesions in the storage tissues of the tuberous roots of infected plants ([17], [22]). Root constrictions are also sometimes observed, as well as brown/black lesions on green fruits, and necrotic lesions in leaf scars. In severe infections these lesions kill dormant axillary buds leading to a general shrinkage of the node and death of the intermodal tissue, so that the branch dies from the tip, causing dieback [23]. Secondary losses occur as a consequence of early harvesting, which farmers use as a strategy to avoid root necrosis [23].CBSD damage on tuberous roots in the form of yellow/brown necrosis results in tissues which are unfit for human consumption [23].

CBSD is known to be caused by a single-stranded RNA virus of the Potyviridae family; genus Ipomoviru s[24].Two genetically distinct strains of CBSVs were recognized in East Africa [25], which are now known to be two distinct species, Cassava brown streak virus (CBSV) and Ugandan cassava brown streak virus(UCBSV)[26].In the early 2000s, cassava root necrosis (Figure 1), similar to that caused by CBSD, was reported in the western provinces of DRC (Kinshasa and Bas-Congo) by Mahungu et al. (2003) [27]. and the then-current PCR diagnoses did not detect any causal agent related to the observed symptoms. From then on, the disease was referred to as 'CBSD-like disease' [28].

Whole genome sequencing of infected material in Tanzania, Uganda, Mozambique, and Kenya, and Zambia has shown that there are several species of UCBSV and CBSV ([29], [30], [31]).

Since 2004, several investigations have been undertaken to identify the causal agent responsible for CBSD-like disease in western DRC using cassava leaf samples including those from plants showing very severe symptoms- with no success to date [28].

More recently, genomic studies using Illumina sequencing showed that no virus was present in any samples with severe root necrosis collected from western DRC. This suggests that microorganisms such as bacteria or fungi could be responsible for cassava root necrosis in western DRC and is not CBSD as predicted (Bakelana et al, unpublished). NGS (Next Generation Sequencing) results confirms all the previous negative results obtained using PCR and CBSV primers [28]. 
This is the first scientific evidence that no currently known virus is responsible for the disease which had been referred to previously as 'CBSD-like disease'. Consequently, the new disease found in western DRC has been designated "Cassava Root Necrosis Disease" or CRND.

Bacteria and fungi isolations work is currently ongoing with the collaboration of the Plant Clinic of Kinshasa and Koch Postulate studies will be carried out to confirm the pathogen city of those microorganisms.

In order to determine the current extent of CRND, a survey was undertaken in 2016 and 2017 in western DRC to assess the severity and incidence of the disease. Thus, five provinces were surveyed from 2016 to 2017. Reports received from several partners indicated that the disease was spreading from Kinshasa and Bas-Congo provinces towards western DRC provinces and towards neighbouring countries ([32], [33]).

\section{MATERIALS AND METHODS}

Surveys were carried out in 2016 and 2017 in western DRC. Five provinces (Bas-Congo, Kinshasa, Bandundu, Equateur and Kasai-Oriental - see Figure 1) were surveyed; the province of Kasai Occidental was not surveyed due to security reasons. As DRC is part of the West African Virus Epidemiology project (WAVE), we used the harmonized field-sampling protocol adopted by the WAVE project -as described in the work of other researchers ([20], [34],[35], [36]).

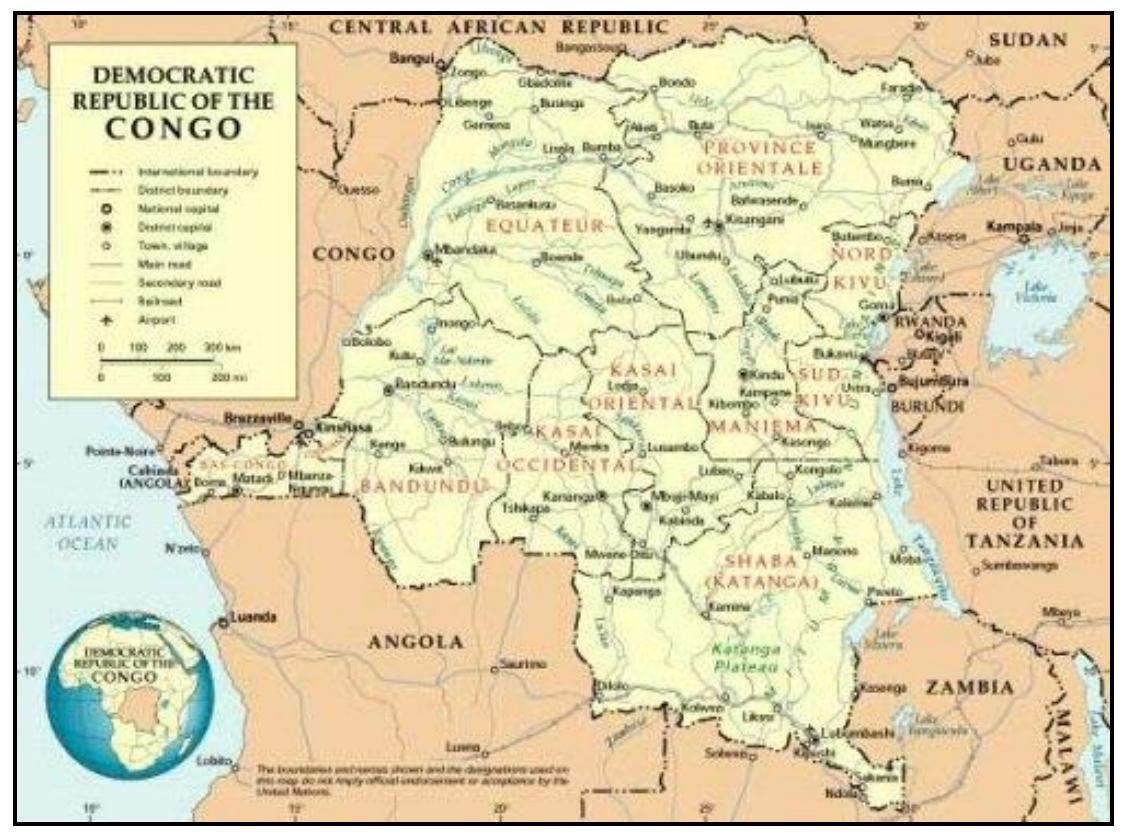

Figure 1: Map of DRC illustrating the country's provinces

A total of 146 fields in the five provinces were surveyed as follows: 29 fields in Equateur, 30 in Kasai-Oriental, 38 in Kinshasa, 26 in Bas-Congo and 23 in Bandundu. Fields of 12-year-old 
plants were selected at regular intervals along roads within each region. Cassava plants of this age were selected to allow the manifestation, if any, of root necrosis. Root necrosis appearance is related to the age of the cassava plant and the assessment is easier for plants older than 12 years. This is the same phenomenon with CBSD where CBSD root necrosis progression increases with plant age [37].

Thirty plants were examined along both diagonals across the field. In each field sampled, 10 plants were uprooted and their tuberous roots were transversely sliced to check for root necrosis. Root symptoms severity was scored on a scale of 1 (no necrosis) to 5 (> 50\% necrotic). Disease incidence was calculated as the percentage of plants with symptoms in relation to the total number of assessed plants. Whitefly abundance was not assessed because there is no confirmation yet that cassava root necrosis disease is transmitted by whiteflies.

Farmers provided information on cassava varieties and crop age but were unable to provide names for some field samples. The longitude and latitude for each sampling site were recorded using a global positioning system (GPS) device. In 2016, data were collected using hard copy survey forms, 2017 the collection process was refined in collaboration with Cambridge University and Rothamsted Research in the UK. Our data collection form was converted into an electronic application that was uploaded onto a tablet.GPS coordinates were collected from different surveyed fields and these allowed us to produce geo-referential maps showing the incidence and severity level of each locality. Survey data were uploaded from the tablet application to the Cambridge University server on Excel files.

Statistical analysis of survey data was carried out using the Statistix 8.0 software[38].Data were submitted to the analysis of variance (ANOVA) in order to verify whether provinces are statistically different in terms of disease severity and incidence. Means comparison and correlation analysis between different parameters (severity, incidence and altitude) were also carried out.

\section{RESULTS AND DISCUSSION}

\subsection{Mapping of the surveyed area.}

GPS coordinates enabled the establishment of geo-referential maps on the presence/absence, severity and incidence of the disease in western DRC.

Data related to the disease are recorded in Figures 2, 3 and 4, below. 
Vol. 4, No. 06; 2019

ISSN: $2456-8643$

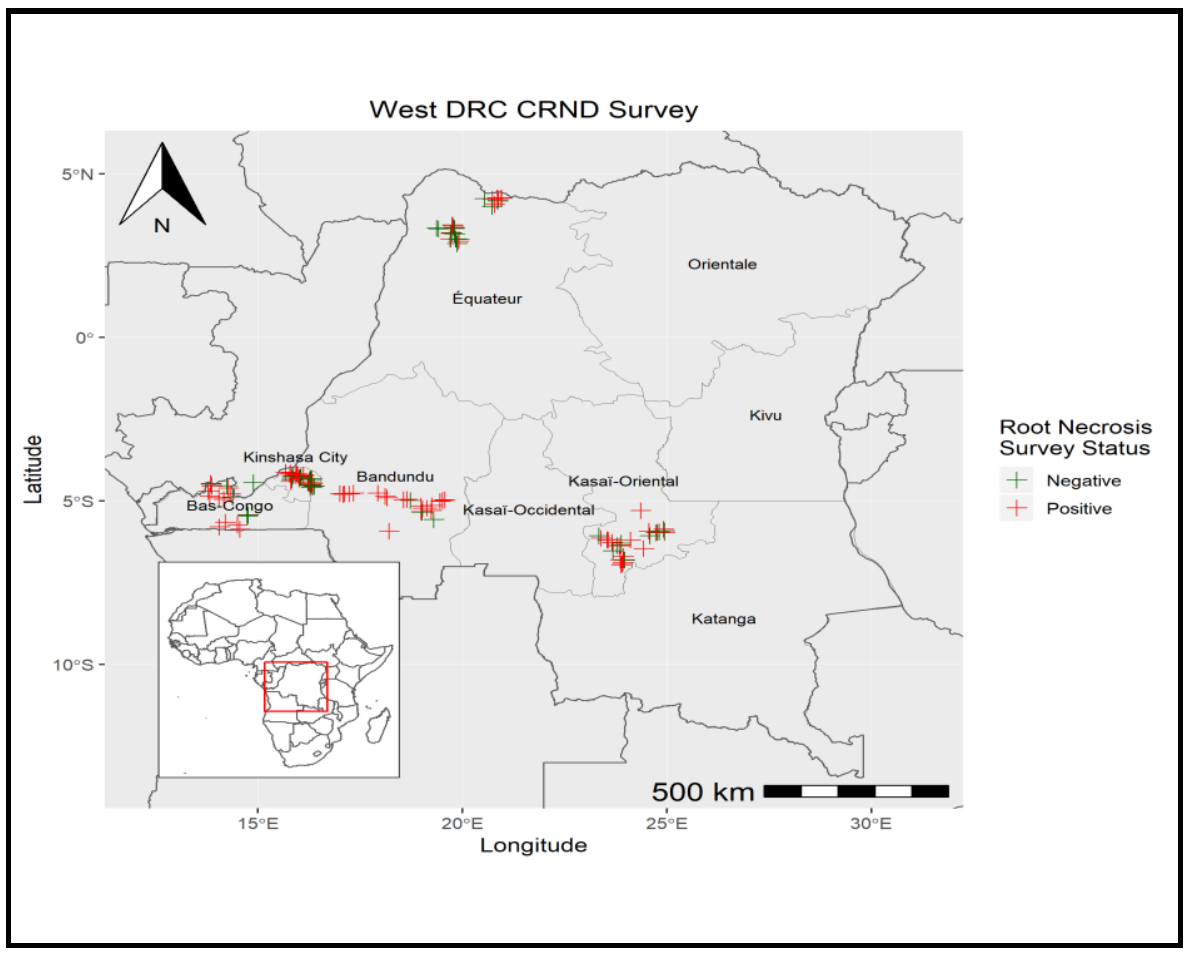

Figure 2: Distribution of CRND in western DRC - CRND is present in all surveyed provinces

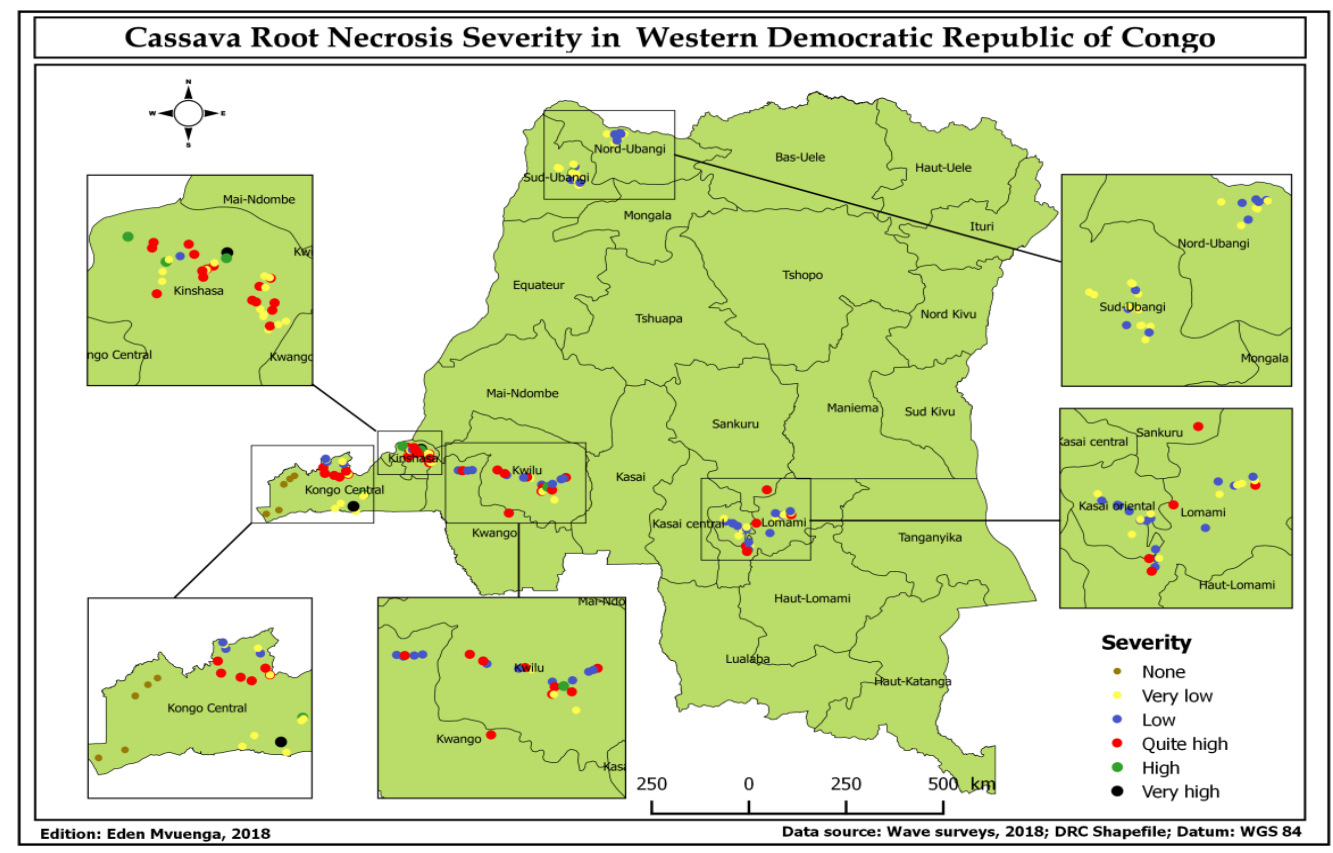

Figure 3; Root necrosis severity in western DRC 


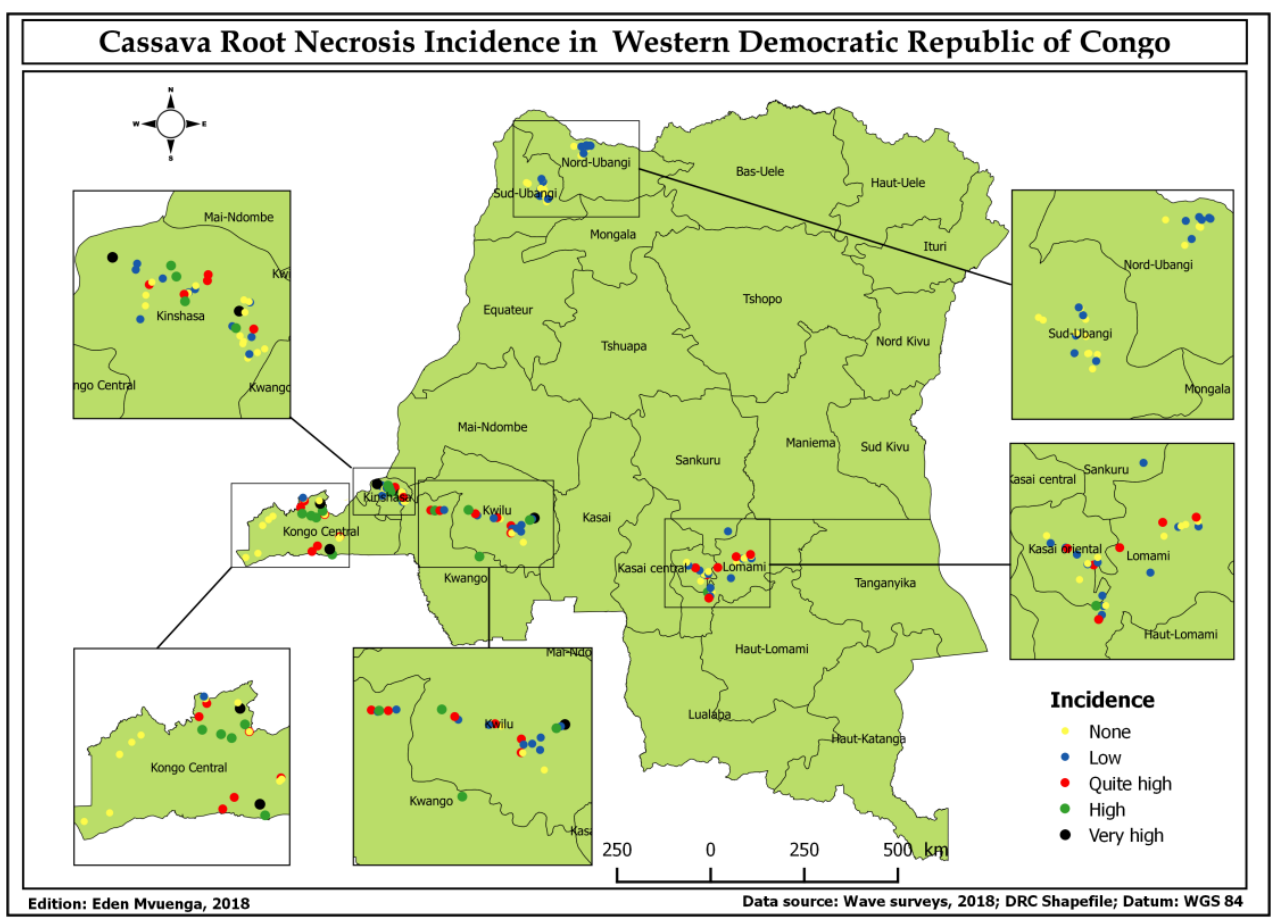

Figure 3: Root necrosis incidence in western DRC

\subsection{Disease severity.}

The ANOVA test and means comparison of severity data from different provinces showed a significant difference $(\mathrm{P}=0.0141)$ with respect to disease severity between the different provinces surveyed (Table 1).

Table 1: Disease severity in provinces surveyed

\begin{tabular}{|l|c|}
\hline Province & Severity \\
\hline Kinshasa & $2.13 \mathrm{a}$ \\
Bandundu & $2.10 \mathrm{a}$ \\
Bas-Congo & $2.08 \mathrm{a}$ \\
Kasai-Oriental & $1.82 \mathrm{ab}$ \\
Equateur & $1.39 \mathrm{~b}$ \\
\hline Mean & 1.87 \\
Std & 0.08 \\
CV & 49.28 \\
\hline
\end{tabular}




\begin{tabular}{|l|c|}
\hline LSD (.05) & $*$ \\
& \\
\hline
\end{tabular}

ANOVA results and means comparison showed the existence of 2 groups significantly different (a and b). Provinces Kinshasa, Bandundu and Bas-Congo are not significantly different from one another them in terms of severity of the disease and are the most affected by the disease while the province of Equateur has the lowest severity. The province of Kasai-Oriental is an intermediate group (ab) which is not significantly different from the two groups mentioned above.

Figure 5 below shows that only Bas-Congo and Kinshasa province presented the highest disease severity (score 3 and 5 respectively). Equateur province had the highest percentage of healthy plants, although some samples presented mild symptoms.

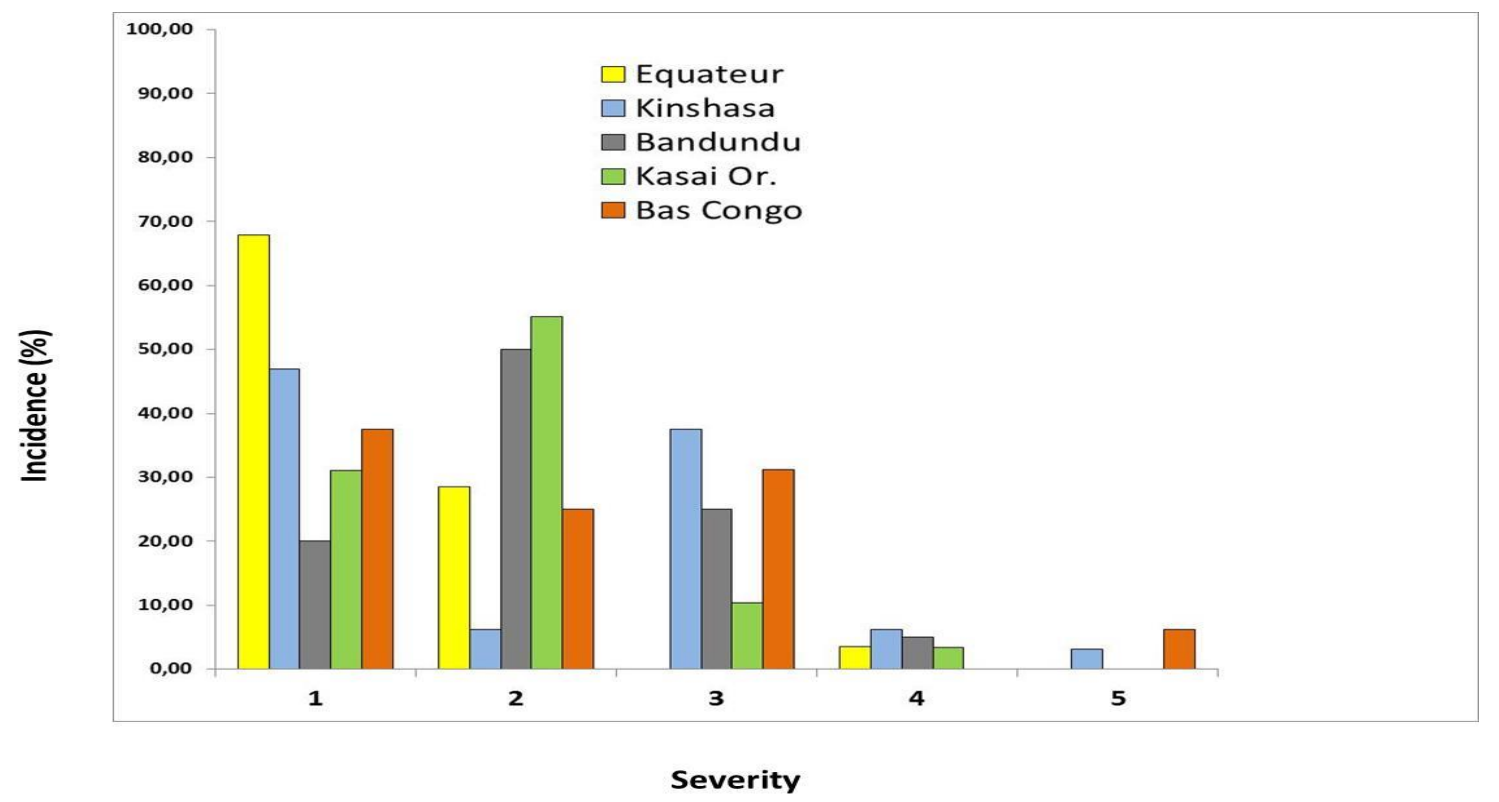

Figure 4: Disease severity in each of the five provinces surveyed

The overall average cassava root necrosis severity during this first exploratory survey in western DRCwasaround $1.88 \pm 0.08$, an approximate score of 2 . 
These results are consistent with the first report of CBSD undertaken in Zambia in July 2017[39]which showed root necrosis mean severity ranging from 2 to 2.3 (mild to moderate). If no control measures are put in place, the overall disease severity average will increase in thenear future.

\subsection{Disease incidence.}

ANOVA and means comparison of data presented in Table 2 below showed that there is a significant difference between different provinces in terms of the incidence of the disease.

Table 2: Disease incidence in provinces surveyed.

\begin{tabular}{|l|c|}
\hline Province & Incidence (\%) \\
\hline Kinshasa & $20.62 \mathrm{c}$ \\
Bandundu & $35.0 \mathrm{ab}$ \\
Bas-Congo & $38.75 \mathrm{a}$ \\
Kasai-Oriental & $21.37 \mathrm{bc}$ \\
Equateur & $6.42 \mathrm{~d}$ \\
\hline Mean & 22.24 \\
Std & 2.4 \\
CV & 120.98 \\
LSD (.05) & $* *$ \\
\hline
\end{tabular}

The means comparison has shown that there are 3 significantly different groups (a, $\mathrm{c}$ and d). BasCongo Province showed the highest incidence of the disease (38.75\% (a)), while the provinces of Kinshasa and Equateur showed the lowest incidences, respectively with $20.62 \%$ (c) and $6.42 \%$ (d).Kasai-Oriental and Bandundu provinces are in two intermediate groups ( $\mathrm{ab}$ and bc) which are not significantly different from groups a and c. The data above confirm that Bas-Congo is the most affected province, while the province of Equateur is the least affected in western DRC. The overall mean incidence of western DRC was $22.24 \pm 2.4 \%$ and reached $100 \%$ in localities considered as hotspots. The same tendency was recorded in Mozambique in 1999 where CBSD incidence reached $80-100 \%$ in some areas and many of the main cassava cultivars were affected [40].

\subsection{CRND hotspots.}


A joint analysis of data on the severity and the incidence of the disease revealed two localities (Lukuakua in Bas-Congo and Nguma in Kasai-Oriental) that we can now consider as hotspots of the disease, with very high levels of severity and incidence (Figure 6).

Hotspots have been variously described as areas of: elevated incidence or prevalence; higher transmission efficiency or risk; or higher probability of disease emergence. In infectious disease epidemiology, the term 'hotspot'is frequently used to refer to areas of elevated disease burden, high transmission efficiency or an area in the natural environment where the disease occurs on a permanent basis $\left([41]_{2}[42]_{2}[43]\right)$. Other localities where there is currently high disease incidence but low disease severity could become hotspots in the near future if contingency measures are not put in place. Instances of these conditions are found at Muluono, Misieme, Kitshini, all in the province of Kinshasa; at Boketa in Equateur province and at Luano in Kasai-Oriental province. These localities can be considered potentials hotspots of the disease in western DRC. Actions to deal with these risks should start at hotspots and potential hotspot localities immediately.

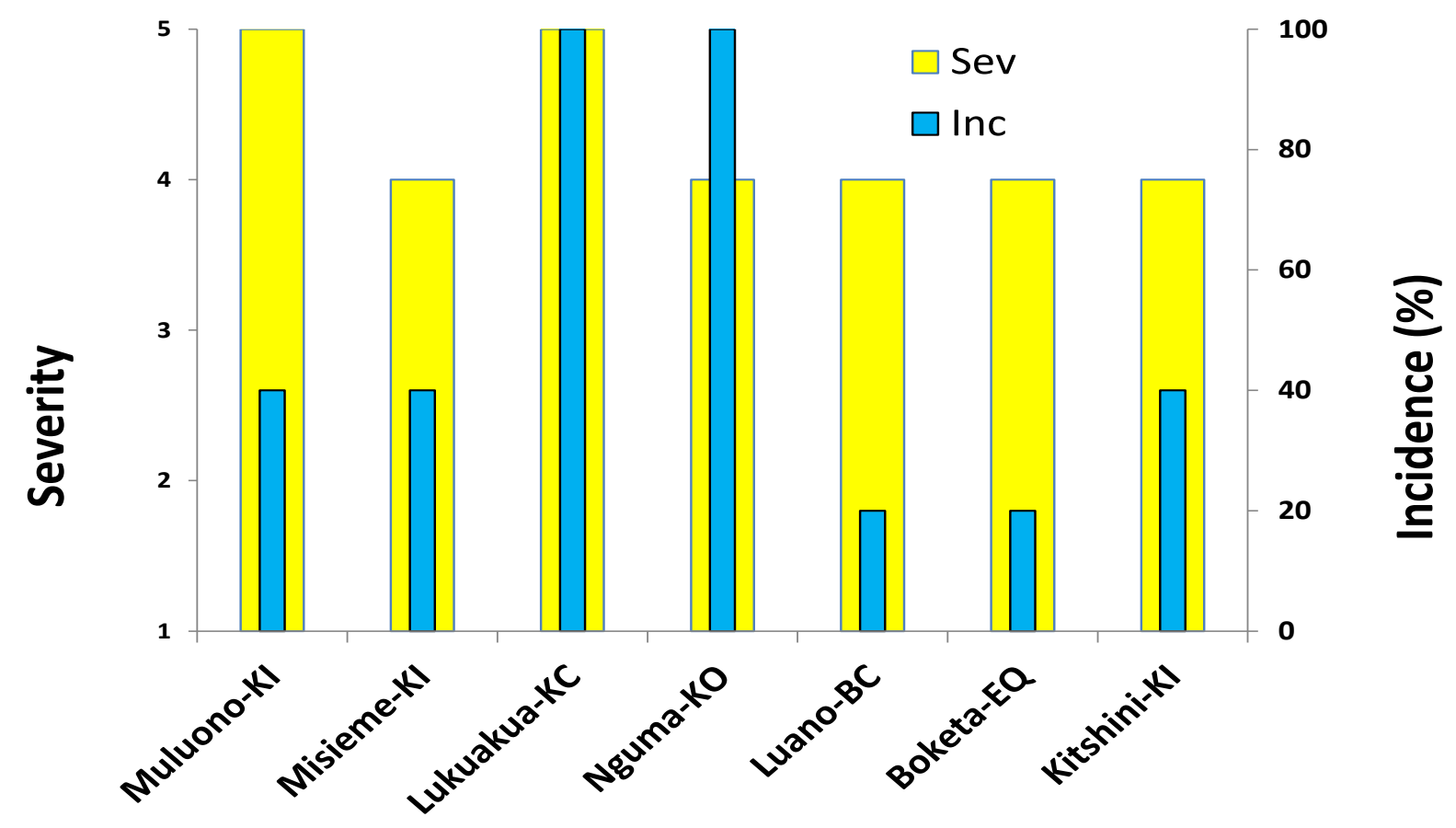

Figure 5: Hotspots and potential hotspot locations in western DRC

\subsection{Cultivars utilization}


During the survey, a clear difference was observed in the use of cassava varieties across different provinces. Improved varieties such as landraces were identified. The list of varieties encountered is presented Table 3 below.

Table 3: Cultivar utilization and effect of disease in the five provinces surveyed

\begin{tabular}{|lllll|}
\hline Cultivars & $\begin{array}{l}\mathrm{N}^{\circ} \\
\text { surveyed } \\
\text { fields }\end{array}$ & $\begin{array}{l}\text { of } \\
\text { surveyed } \\
\text { fields }\end{array}$ & of Severity & $\begin{array}{l}\text { Incidence } \\
(\%)\end{array}$ \\
\hline Obama & $31^{*}$ & 24.8 & 2.5 & 45.16 \\
RAV & $18^{* *}$ & 14.4 & 2.5 & 55.55 \\
Kaele & 8 & 6.4 & 2.27 & 75.0 \\
Other cultivars & 63 & 4.0 & 1.8 & 80.0 \\
Total & 125 & 50.4 & 2.53 & 58.06 \\
Mean & & 100 & $\mathrm{n} / \mathrm{a}$ & $\mathrm{n} / \mathrm{a}$ \\
Std & - & & & \\
CV $(\%)$ & 23.55 & 18.84 & 0.31 & 14.41 \\
\hline
\end{tabular}

(*) 22 fields in Equateur, 6 fields in Kinshasa and 3 fields in Bandundu.

(**) 2 fields in Equateur, 2 fields in Kinshasa and 14 fields in Bas-Congo.

The Obama variety whose pedigree is TME 419 was encountered more frequently in the Equateur province. This variety was introduced to DRC in 2010 from IITA-Ibadan through the research center of INERA-Mvuazi. It was initially widely accepted in Kinshasa and Bas-Congo due to its high dry matter content, its high fresh tuberous root yield and the quality of its processed products,such as $f u f u$ and chikwangue. But a few years later, after its wide distribution and adoption in Bas-Congo province and Kinshasa, this variety became highly susceptible to cassava root necrosis and IITA and INERA officially withdrew it from the official list of cassava varieties to be promoted and cultivated in DRC (DRC Ministry of Agriculture, 2015).Asa result, this variety was abandoned by farmers in the provinces of Kinshasa and Bas-Congo. Table 3illustratesthat this variety continues to be cultivated intensively in the Equateur province, where necrosis disease is not yet a threat to cassava cultivation.

The RAV variety is the most cultivated variety in Bas-Congo province and is among the most susceptible varieties to root necrosis [32].Landraces such as Biele and Kamana-Mabanza were 
encountered during the surveys and these also presented root necrosis symptoms. This contradicts the hypothesis that landraces are resistant to root necrosis and is in accordance with results of Bakelana et al. (2018) [32].and Bakelana et al. (2019b) [33]showing that the RAV variety was also susceptible to root necrosis, as was the case in the north of Angola and southwestern DRC.

Our study results showed that the behavior of cassava varieties to CRND is similar to their response to CBSD: most of improved varieties and landraces are shown to be sensitive to CRND (Table 3).

The first CBSD survey in Mozambique in 1999, showed that most of the common cassava cultivars grown in Mozambique (Zambezia and Nampula provinces) were affected by CBSD [40]. Due to current susceptibility of all cassava varieties in DRC to CRND, the recommendation to farmers in zones with high disease pressure is to prematurely harvest cassava fields in order to avoid root losses caused by CRND [40]. This is the main control measure recommended while waiting for the release of resistant varieties.

This would follow the strategy used in East Africa, including areas of Tanzania where CBSD is endemic. CBSD root symptoms usually begin to appear in cassava grown from infected cuttings at around 5-7 months after planting. Once root symptoms appear, they become progressively more severe the longer the crop remains in the field. Farmers harvest their cassava fields prematurely to avoid such root necrosis damage. A drawback of this strategy is that that the crop is harvested before reaching its full yield potential and it cannot be kept in the field as a food reserve in the event of famine during the dry season [45].

\subsection{Correlation analysis}

Correlation analyses (Table 4) made between different parameters showed a significant difference between root necrosis severity and incidence. There is indeed a positive correlation ( $\mathrm{r}$ $=0.6940$ ) between these two parameters. This corroborates most of the results available on cassava brown streak disease in East Africa [44].

No correlation was found between the altitude and disease. The locality of Luozi (Bas- Congo province) constitutes the lowest zone of the surveyed area and the locality of Lukangu (KasaiOriental province) represents the culminating point and no significant difference $(\mathrm{p}=0.5455)$ was found between the altitude parameter and the manifestation of the disease. In general, the entire area of western DRC consists of plains and plateaus. Very few high-altitude areas (mountain chain) are found in western DRC and where there are hills; cassava is generally grown in lowlands. 
Table 4: Correlation of CRND severity in relation to CRND incidence and altitude

\begin{tabular}{|lllll|}
\hline Parameter 1 & Parameter 2 & Coefficient & P value & Significance \\
\hline CRND severity & $\begin{array}{l}\text { CRND } \\
\text { incidence }\end{array}$ & 0.6940 & 0.0000 & $* *$ \\
CRND severity & Altitude & 0.0546 & 0.5455 & ns \\
\hline
\end{tabular}

Ns Not significant

$*_{-}$Significant at $\mathrm{P}<0.05$ level.

**- Significant at $\mathrm{P}<0.01$ level.

\section{CONCLUSION}

This study aimed to determine the current distribution, severity and incidence of CRND in western DRC. Our results have shown that the disease affects all provinces in western DRC but at different levels of severity and incidence. From our exploratory survey conducted in western DRC in 2016 and 2017, we set out below our observations and recommendations.

If no control measure is put in place, the overall disease severity and incidence average is likely to increase in the near future in western DRC and the disease is also likely to spread to eastern DRC where CBSD has been confirmed already. We request the Congolese government or their partners (donors, etc.) to provide funds in order to implement the strategies formulated in the DRC national plan. This plan was the country's response to cassava viral disease control as discussed in Kinshasa in November 2018 and ratified by the DRC Ministry of Agriculture.

Further investigation should also be conducted in the eastern DRC where CBSD has been confirmed. This would enable us to know if root necrosis occurs in the same environment as CBSD and to report if there are cases of mixed infections. Should these two diseases, which cause similar root symptoms, affect cassava simultaneously in the same area of western or eastern DRC, the consequences for cassava production would be very serious.

The potential impact of mixed CBSD and CRND infections are outlined here. As these two distinct diseases would be indistinguishable at the field level, plant material would need to be screened and viruses differentiated using molecular tools. This would present a serious issue due to the country's current limited research infrastructure (e.g. laboratories)to tackle this work. At the farmer level, the implementation of control methods, such as phytosanitation, choice of varieties and lands, would be complex and difficult to achieve. Therefore, we consider that there is an urgent need for the development of phytosanitary and regulatory measures to restrict the further spread of both diseases. 
The presence of CRND in western DRCand CBSD in eastern DRChas implications for the movement of cassava germplasm within the country and for Central Africa. Thus, this study highlights the need - at the government level - to establish an open quarantine system between the DRC and its neighbours to control the movement of cassava germplasm within DRC and throughout the central African region. Additionally, we need to facilitate the exchange of disease-indexed tissue culture plantlets among neighbouring countries. This will require the establishment of a rapid and robust CRND and CBSD diagnostics capability within several hubs in western and eastern DRC.

For medium-term disease control, our work suggests that the development and deployment of control measures should be a priority; these measures include the use and deployment of cultivars resistant to CRND and CBSD.

\section{ACKNOWLEDGEMENTS}

This work was fully funded by the Bill and Melinda Gates Foundation and Department for International Development (DFID) Grant no. OPP1082413 'West African Virus Epidemiology (WAVE) for root and tuber crops' through a sub grant from Université Félix Houphouët-Boigny (UFHB).We are grateful to the AgShare.Today team who assisted with the editing of this manuscript and to INERA for all administrative and technical facilities provided to us to achieve this survey. Thank you also to all local authorities and farmers who received our survey teams in their villages and fields and permitted data collection.

\section{REFERENCES}

[1] IITA, "Cassava (Manihot esculenta)". International Institute of Tropical Agriculture.https://en.wikipedia.org/wiki/Cassava_production_in_the_Democratic_Republic_of the Congo\#cite ref-3, 2015.

[2] Nweke, Felix I. "The Cassava Transformation in Africa". Food and agricultural Organization $(F A O)$.https://en.wikipedia.org/wiki/Cassava_production_in_the_Democratic_Republic_of_the_ Congo\#cite_note-Nweke-4

[3]Facts On File, Inc. , "Encyclopedia of the Peoples of Africa and the Middle East". Infobase Publishing. ISBN978-1-4381-2676-0, 2009.

[4] Mbago-Bhunu, Sara; LotombeBolema, Gérard. "Democratic Republic of Congo: Improving cassava production and supply systems"(PDF). SNV Netherlands Development Organisation.https://en.wikipedia.org/wiki/Cassava_production_in_the_Democratic_Republic_o f_the_Congo\#cite_note-Bhunu-1

[5]B. Rajeev, A. AbdKarim, G. Paliyath, "Progress in Food Preservation". John Wiley \& Sons, 2012.ISBN978-1-119-96202-1.

[6]American University.Foreign Areas Studies Division (1971). Area handbook for the Democratic Republic of the Congo (Congo Kinshasa). Washington, D.C.: U.S. Government 
Vol. 4, No. 06; 2019

ISSN: $2456-8643$

Printing Office.

[7] J. Bruinsma, "World Agriculture: Towards 2015/2030: an FAO Perspective". Earthscan, 2003.ISBN978-1-84407-007-7.

[8] J. Mbwika, S. Lukombo, M. Khonde, "Cassava Sub-Sector Analysis - Draft Field Survey Report", 2015.

[9] S.K. Hahn and J. Keyser, "'Cassava, a basic food of Africa”. Outlook Agric.14 : 95-99, 1985.

[10] J.P. Legg \& C.M. Fauquet, "Cassava mosaic geminiviruses in Africa". Plant Molecular Biology, 56(4), 585-599. https://doi.org/10.1007/s11103-004-1651-7, 2004.

[11] C. Fauquet, D. Fargette \& C. Munihor, "African Cassava Mosaic Virus : Etiology, Epidemiology, and Control." 74(6), 1990.

[12] S.K. Hahn, E. Terry \&K.. J. Leuschner, “Breeding cassava for resistance to cassava mosaic disease". Euphytica, 29, 673-683, 1980.

[13] A. Muimba-Kankolongo, \& K. Phuti, "Relationship of Cassava Mosaic Severity in Planting Material to Mosaic Development, Growth and Yield of Cassava in Zaire". Experimental Agriculture,23(2), 221-225, 1987. doi:10.1017/S0014479700017026

[14] K.M. Lema, A. Dixon, N. Mahungu, P. Ilona, S. Nluta, S. Lukombo, \& S. Bidiaka, “ Strategic cassava production rehabilitation in the Democratic Republic of Congo". In N. M. Mahungu, \& V. M. Manyong (Eds.), Advances in Root and Tuber Crops Technologies for Sustainable Food Security, Improved Nutrition, Wealth Creation and Environmental Conservation in Africa (pp. 540-547). Proceedings of the 9th ISTRC-AB Symposium; Mombassa, Kenya, November 1-5, 2007.

[15] W. Tata-Hangy, J. Legg, R. Hanna, M. Toko, K..M. Lema, A. Dixon, \& N.M. Mahungu, "Incidence and distribution of cassava diseases and pests in the Democratic Republic of Congo". In N. M. Mahungu, \& V. M. Manyong (Eds.), Advances in Root and Tuber Crops Technologies for Sustainable Food Security, Improved Nutrition, Wealth Creation and Environmental Conservation in Africa (pp. 540-547). Proceedings of the 9th ISTRC-AB Symposium; Mombassa, Kenya, November 1-5, 2007.

[16] R.J. Hillocks, M.D. Raya, K. Mtunda and H. Kiozia, 'Effects of Brown Streak Virus Disease on Yield and Quality of Cassava in Tanzania". Journal of Phytopathology, 149: 389-394, 2001. doi:10.1111/j.1439-0434.2001.tb03868.x

[17] HH. Storey, "Virus diseases of East African plants: VI-A progress report on studies of the disease of cassava". East Africa Agricultural Journal 2:34-39, 1936.

[18] G. M. Rwegasira, G.Momanyi, M.E.C. Rey, G. Kahwa, \& J.P. Legg, "Widespread occurrence and diversity of Cassava brown streak virus (Potyviridae: Ipomovirus) in Tanzania". Phytopathology 101:1159-1167, 2011.

[19] R.F. Nichols, "The brown streak disease of cassava: distribution climatic effects and diagnostic symptoms". East African Agricultural Journal15:154- 160, 1950.

[20] T. Alicai, C.A. Omongo, M.N. Maruthi, R.J. Hillocks, Y., Baguma, R. Kawuki, A. Bua, G.W. Otim-Nape \& J. Colvin, Re-emergence of cassava brown streak disease in Uganda. Plant Disease 91 (1): 24- 29, 2007. 
[21] W.Mulimbi, X. Phemba, B. Assumani, P. Kasereka, S. Muyisa, H. Ugentho, L. Laurenson, "First report of Ugandan cassava brown streak virus on cassava in Democratic Republic of Congo". New Disease Reports 26, 11, 2012. [http://dx.doi.org/10.5197/j.20440588.2012.026.011]

[22] J.P. Legg, S.C. Jeremiah \& M.M.N. Gowda, "Comparing the regional epidemiology of the cassava mosaic and Cassava brown streak virus pandemics in Africa"; 2011. https://doi.org/10.1016/j.virusres.2011.04.018

[23] R. Hillocks \& D. Jennings, "Cassava brown streak disease: A review of present knowledge and research needs". International Journal of Pest Management, 49(3), 225-234, 2003.

https://doi.org/10.1080/0967087031000101061

[24] W.A. Monger, S. Seal, A..M. Isaac \& G.D. Foster, " Molecular characterization of the Cassava brown streak virus coat protein". Plant Pathology, 50(4), 527-534, 2001. https://doi.org/10.1046/j.1365-3059.2001.00589.x

[25] D.R. Mbanzibwa, Y.P. Tian, K. Tugume, S.B. Mukasa, F. Tairo, S. Kyamanywa \& J.P.T. Valkonen, "Genetically distinct strains of Cassava brown streak virus in the Lake Victoria basin and the Indian Ocean coastal area of East Africa". Archives of Virology, 154(2), 353-359, 2009. https://doi.org/10.1007/s00705-008-0301-9

[26] W.A. Monger, T. Alicai, J. Ndunguru, Z.M. Kinyua, M. Potts, R.H. Reeder \& J. Smith, "The complete genome sequence of the Tanzanian strain of Cassava brown streak virus and comparison with the Ugandan strain sequence". Archives of Virology, 155(3), 429-433, 2010. https://doi.org/10.1007/s00705-009-0581-8

[27] N.M. Mahungu, M. Bidiaka, W. Tata, S. Lukombo\& S. N'luta, "Cassava brown streak disease-like symptoms in Democratic Republic of Congo". ROOTS; 8: 8-9, 2003.

[28] Z. Bakelana, E. Magembe, L. Boykin, M. Macharia, N. Mahungu, W.Tata, D. Lutete, G. Monde, H. Jagger, J. Ndunguru, C. Kayuki, J.Pita, KM. Lema, K. Tshilenge, "Attempts to Identify Cassava Brown Streak Virus in Western Democratic Republic of Congo". Journal of Agricultural Science, 11(2), 31, 2019. https://doi.org/10.5539/jas.v11n2p31

[29] J. Ndunguru, P. Sseruwagi, F. Tairo, F. Stomeo\& S. Maina, "Analyses of twelve new whole genome sequences of cassava brown streak viruses and Ugandan cassava brown streak viruses from East Africa: diversity, supercomputing and evidence for further speciation". PLoS One 10 (10): e0141939, 2015.

[30] E. Ateka, T. Alicai, J. Ndunguru, F. Tairo, P. Sseruwagi, S. Kiarie, T. Makori, T., M.A. Kehoe \& L. Boykin, "Unusual occurrence of a DAG motif in the ipomovirus Cassava brown streak virus and implications for its vector transmission”. PLoS One 12:e0187883, 2017.

[31] J.J.G. Amisse, 'Molecular Characterization of Cassava Brown Streak Viruses in Mozambique", Thesis submitted for MSc degree at University of Witwatersrand, Johannesburg, South Africa, 2013.

[32] Z. Bakelana, Z. Musben, L. Boykin, J. Pita, A. Mvila, G. Monde, N.M. Mahungu, J. Legg, J. Mpika, K.M. Lema, \& K. Tshilenge, "First Report and Preliminary Evaluations of Cassava Brown Streak-Like Root Necrosis in Congo Republic", International Journal of Development Research, 8, (08), 22400-22407, 2018.

[33] Z. Bakelana, L. Boykin, M.N. Mahungu, N.Mavila, M. Matondo, M. Lufuankenda, N.Tevo, G. Monde, J. Pita, K.M. Lema, K. Tshilenga, "First report and preliminary evaluation of cassava root necrosis in angola. International Journal of Agriculture, Environment and BioresearchVol. 4, 
No. 03; 2019 ISSN: 2456-86434(03), 37-46, 2019.

[34]J.P. Legg, \& M.D. Raya, "Survey of cassava virus diseases in Tanzania.International Journal of Pest Management, 1998. https://doi.org/10.1080/096708798228473

[35] P. Ntawuruhunga, G. Okao-Okuja, A.Bembe, M. Obambi, A. Mvila\& JP Legg, J.P, "Incidence and Severity of Cassava Mosaic Disease in the Republic of Congo". African Crop Science Journal, Vol. 15, $\mathrm{N}^{\circ} 1$, pp 1-9, 2007.

[36] P. Sseruwagi, W.S. Serubombwe, J.P. Legg, J. Ndunguru, \& J.M. Thresh, "Methods of surveying the incidence and severity of cassava mosaic disease and whitefly vector populations on cassava in Africa: a review". Virus Res. 100, 129-142, 2004.

[37] A. Abaca, S.R. Kawuki, P. Tukamuhabwa, Y. Baguma, A. Pariyo, J. Orone, T. Alicai, A. Bua\& C. Omongo, "Progression of Cassava Brown Streak Disease (CBSD) in infected cassava roots in Uganda". Uganda Journal of Agricultural Sciences, 2012, 13 (1): 45-51, 2012.

[38] Statistix8.0 Analytical Software, Tallahassee, Florida, 2003

[39] R. Mulenga, M. Makulu, L. Boykin, P. C. Chikoti \& S. Sichilima, 'Cassava Brown Streak Disease and Ugandan cassava brown streak virus Reported for the First Time in Zambia”, 2018. https://doi.org/10.1094/PDIS-11-17-1707-RE

[40] R.J. Hillocks, J. M. Thresh, J. Tomas, M. Botao, R. Macia \& R. Zavier, "Cassava brown streak disease in northern Mozambique”. International Journal of Pest Management, 48(3), 178181, 2002. https://doi.org/10.1080/09670870110087376

[41] P. Bejon, TN Williams, A. Liljander, A.M. Noor, J. Wambua, E. Ogada, A. Olotu, F.H.Osier, S.I. Hay, A. Färnert, K. Marsh, "Stable and unstable malaria hotspots in longitudinal cohort studies in Kenya".

PLoS Med. 2010 Jul 6; 7(7):e1000304.

[42] K.C. Ernst, S.O. Adoka, D.O. Kowuor, M.L. Wilson \& C.C. John, "Malaria hotspot areas in a highland Kenya site are consistent in epidemic and non-epidemic years and are associated with ecological factors". Malaria Journal, 5 (May 2014). https://doi.org/10.1186/1475-2875-5-78

[43] J. Lessler, A.S. Azman, H.S. McKay \& S.M. Moore, "Perspective piece: What is a hotspot anyway?" American Journal of Tropical Medicine and Hygiene, 96(6), 1270-1273, 2007. https://doi.org/10.4269/ajtmh.16-0427

[44] K. Katono, T. Alicai, Y. Baguma, R. Edema, A.Bua \& C.A. Omongo, "Influence of Host Plant Resistance and Disease Pressure on Spread of Cassava Brown Streak Disease in Uganda."7(5), 284-293, 2015. https://doi.org/10.9734/AJEA/2015/15563 